\title{
PERSEPSI KOMUNITAS "ARSENAL" BANDUNG TERHADAP PESAN PERINGATAN PADA BUNGKUS ROKOK
}

\author{
Muhammad Hanif Ahda \\ Ilmu Komunikasi Fakultas Ilmu Sosial dan Politik \\ Universitas Abdurrab Pekanbaru (RIAU) \\ Email: Hanif.Ahda@univrab.ac.id
}

\begin{abstract}
Cigarettes are the product that leads to the pros and cons the people of Indonesia. Negative effects due to smoking no doubt, substances in cigarettes to be an indicator of various diseases of cigarettes to consumers. The government has issued a rule requiring cigarette manufacturers to the dangers of smoking message by including images warning of the dangers of smoking. This study aims to determine the perceptions of community members regarding visual warning label smoked edition of "lungs damaged". Data collection techniques used in this research through interviews, observation, documentation. This study refers to the theories of perception ecology, how the stages of processing human perception occurs, that man's way of responding to a stimulus environmental, cultural backgrounds and communities, through the method of the message fear appeals, on delivery through media spooky image on cigarette packs. Results of research conducted by researchers at the community Arsenal Indonesian Supporter is a positive perception of the members of that community, and the message delivered by the government through the media picture warnings to be put on artificial cigarette packs in particular edition of "lungs damaged" conveyed properly, it is evident by reduced consumption rate of smokers in the community. Thus, it can be concluded that government regulation regarding the rules for the inclusion of the dangers of smoking images on cigarette packs is a good effort although still not very effective but enough make community members AIS Bandung smokers reduce smoking intensity and some have quit smoking.
\end{abstract}

Keywords: Perception, cigarette, warning messages, Arsenal Indonesian Supporter community

\section{A. PENDAhULUAN}

Saat ini merokok yang dilakukan oleh masyarakat Indonesia sering bersamaan dengan kegiatan lain, salah satunya adalah kegiatan menonton bareng sepak bola, kegiatan merokok sudah bukan hal yang biasa lagi, bahkan hal ini sudah menjadi sebuah kewajiban 
bagi sebagian penonton sepak bola berlangsung. Bila saat nonton pertandingan berlangsung penonton tidak henti-hentinya mengepulkan asap rokok sambil menikmati secangkir kopi panas. Pada umumnya nonton bareng sepak bola kebanyakan dilakukan di warung-warung kopi dan Cafe. Apalagi Bandung sudah sangat terkenal dengan warung kopi dan Cafe yang sangat banyak. Para pengelolanya pun tahu apa yang diingini oleh masyarakat. Mereka menyediakan fasilitas, lengkap dengan layar lebarnya.

Maka tidak heran jika hampir di semua warung kopi dan Cafe dilengkapi dengan layar lebar. Tapi meski demikian, menonton bola sambil merokok dan minum kopi adalah sesuatu yang lumrah terjadi dimana-mana. Apalagi pertandingan sepak bola selama ini berlangsung pada malam hari. Maka untuk tidak mengantuk atau untuk mengisi waktu sambil menunggu pertandingan tengah malam merokok, dan minum secangkir kopi adalah salah solusinya, karena kebiasaan itulah tidak heran jika kemudian dengan serta merta para produsen rokok berlomba-lomba untuk menjadi sponsor utama siaran langsung sepak bola.

Hal ini juga terjadi pada Arsenal Indonesian Supporter (AIS) Regional Bandung, AIS Region Bandung ini terbentuk tanggal 27 September 2007 silam, terbentuk secara resmi, menginduk pada AIS pusat yang sudah berdiri di Jakarta sejak tahun 2003. AIS sendiri adalah bentuk salah satu komunitas pendukung team sepak bola asal London, Inggris yang selalu setia memberi dukungan kepada team kesayangan mereka tersebut. Komunitas ini telah hadir di setiap kota di seluruh Indonesia, ketika itu anggota Arsenal Indonesian Supporter (AIS) Regional Bandung yang hadir di acara nonton bareng hanya belasan orang dari sekitar 50 orang yang ada di grup www.id-Arsenal.com, namun lambat laun anggota Arsenal Indonesian Supporter (AIS) Regional Bandung yang hadir nonton bareng pun semakin bertambah. Dan hal inilah yang menjadi kasus unik yang diangkat oleh peneliti untuk diteliti lebih dalam mengenai kebiasaan merokok anggota komunitas Arsenal Indonesian Supporter regional Bandung yang dilakukan bersamaan dengan kegiatan nonton bareng pertandingan sepak bola liga inggris khususnya pertandingan Arsenal Football Club. Bahkan sekarang ini, anggota atau member Arsenal Indonesian Supporter (AIS) Regional Bandung sudah mencapai sekitar 600-an orang tapi kalau disatukan dengan simpatisan bisa dua kali lipatnya, dan setiap kali melakukan nonton bareng anggotanya yang hadir bisa mencapai 100 hingga 200 orang. 
Indonesia sendiri merupakan pasar rokok potensial mengingat pertumbuhan ekonomi yang selalu meningkat $6 \%$ per tahun dan jumlah kelas menengah yag diperkirakan naik hampir dua kali lipat 4 juta jiwa pada 2012 emnjadi 140 juta jiwa pada 2020. Hal ini terlihat pada data pertumbuhan konsumsi rokok yang naik drastis dari 251 miliar batang pada 2009 menjadi 302 miliar batang pada 2012, konsistensi dengan pertumbuhan produk domestik bruto per kapita US\$2.500 pada tahun 2009 menjadi US\$ 3.500 perkapita pada $2020^{1}$.

Jumlah perusahaan di industri pengolahan tembakau besar dan sedang nasional pada 2010 diperkirakan 897 perusahaan, sebaran terbesar terdapat di Jawa Timur. Selain itu industri tembakau juga terdapat di jawa tengah, sumatera utara, jawa barat, dan DI Yogyakarta. Hal ini menunjukan semakin kuatnya dominasi pemain besar di industri ini. Pada tahun 2011-2015, kementrian perindustrian menargetkan pertumbuhan produksi rokok berkisar rata-rata 3\%-4\% pertahun Pada tahun 2006 kalangan industri rokok di dalam negeri telah memberikan kontribusi terhadap penerimaan negara dari pembayaran cukai rokok sebesar Rp 42 triliun. Apabila diperhitungkan dengan pembayaran berbagai jenis pajak lainnya, maka total kontribusi industri rokok terhadap penerimaan negara pada tahun 2006 saja mencapai Rp 52 triliun. Selain memberikan kontribusi terhadap penerimaan negara yang sangat besar, industri rokok kretek di dalam negeri, khususnya yang memproduksi Sigaret Kretek Tangan (SKT) juga mampu menampung tenaga kerja yang sangat besar, yaitu 6 juta orang ${ }^{2}$.

Namun epidemik tembakau di dunia menurut World Health Organization (WHO) menunjukan 1 kematian karena tembakau di seluruh dunia terjadi tiap 6 detik, kematian karena tembakau pada tahun 2005 tercatat sebanyak 5,4 juta jiwa dan selama abad ke 20 terjadi sebanyak 100 juta kematian akibat tembakau. Jika hal ini dibiarkan maka akan terjadi 8 juta kematian pada tahun 2030 dan diperkirakan akan terjadi kematian sebanyak 1 milyar jiwa akibat tembakau selama abad ke 21. Pada tahun 2030, diproyeksikan $80 \%$ kematian terkait tembakau terjadi di negara berkembang. Global Youth Tobacco Survey (GYTS) Indonesia tahun 2006 melaporkan > 37,3\% pelajar (usia 13 - 15 tahun) memulai kebiasaan merokok. Dari sebatang rokok mengandung 4000 bahan kimia beracun dan tidak

\footnotetext{
${ }^{1}$ http://id.wikipedia.com

${ }^{2}$ http://www.bisnis.com
} 
kurang dari 69 di antaranya bersifat karsinogenik. Sehingga rokok dan lingkungan yang tercemar asap rokok dapat membahayakan kesehatan. Hasil Riskesdas tahun 2013 menyebutkan prevalensi perokok di Indonesia mencapai 36,5\% yang terdiri dari $68,8 \%$ perokok laki-laki dan 6,9\% perokok perempuan. Meningkatnya prevalensi merokok maka meningkat pula beban penyakit dan ekonomi akibat dari konsumsi rokok serta menurunnya derajat kesehatan dan kualitas Sumber Daya Manusia (SDM) Indonesia pada masa yang akan datang Fakta ini menempatkan Indonesia di peringkat ketiga dalam hal epidemik konsumsi rokok tertinggi di dunia. Kandungan bahan kimia tersebut dapat menyebabkan berbagai penyakit tidak menular seperti jantung dan gangguan pembuluh darah, stroke, kanker paru, dan kanker mulut. Selain itu, rokok juga dapat menyebabkan penurunan kesuburan, pertumbuhan janin baik fisik maupun IQ (Intelegent Quotient) yang melambat, gangguan imunitas bayi, dan peningkatan kematian. Hal ini tidak terlepas dari semakin gencarnya industri rokok yang tidak pernah sepi memasarkan produknya, karena semakin hari semakin bertambah peminat rokok di kalangan masyarakat ${ }^{3}$.

Namun komitmen pemerintah terkait kebijakan tentang rokok masih lemah, dan berjalan tanpa pengawasan. Hal ini dapat dilihat dari belum adanya undang- undang yang tegas dan ketat mengatur masalah rokok. Lemahnya peraturan pemerintah tentang iklan, promosi dan sponsor rokok di Indonesia juga sangat berpengaruh sehingga berdampak pada agresivitas kegiatan produksi dan penjualan industri rokok.

Untuk mengendalikan hal tersebut, pemerintah mengeluarkan peraturan yang tertuang dalam Peraturan Pemerintah (PP) Hal ini diberlakukan karena nasehatnya untuk berhenti merokok atau larangan merokok disuarakan melalui gambar penyakit yang menyeramkan. Berlakunya peringatan bahaya merokok dengan foto mengerikan ini sejak 24 juni 2014 yang sesuai dengan PP 109/2012 dan Permenkes No.28. Tidak hanya produk lokal yang mewajibkan gambar seram ini, produk luar pun berkewajiban untuk mengikuti peraturan ini. Apabila ada pabrik rokok yang tidak mengikuti peraturan ini akan dikenakan sanksi lima tahun penjara atau membayar denda Rp 500 juta bagi pihak yang secara sengaja tidak mencantumkan peringatan tersebut. Oleh karena itu berdasarkan uraian diatas, penulis tertarik untuk mengkaji bagaimana persepsi komunikasi visual peringatan pada bungkus

\footnotetext{
${ }^{3}$ http://www.kemenperin.go.id
} 
rokok dengan pendekatan studi kasus pada komunitas Arsenal Indonesian Supporter (AIS) regional Bandung.

\section{B. TINJAUAN PUSTAKA}

Berikut adalah beberapa hasil penelitian sejenis yang manjadi acuan dan referensi penulis untuk melakukan penelitian:

a. Penelitian Thesis oleh Yudha Mulyana yang berjudul "Analisis perilaku konsumen rokok dikalangan mahasiswa Universitas Pakuan" Fakultas Ekonomi Universitas Pakuan, Bogor, Jawa Barat pada tahun 2012. Metode yang digunakan dalam penelitian ini adalah metode survei untuk memperoleh gambaran yang jelas mengenai objek yang diteliti. Materi yang disurvei adalah data umum responden, perilaku dan persepsi konsumen. Kesimpulan penelitian adalah bahwa mahasiswa Universitas Pakuan memiliki pengetahuan yang tinggi tentang rokok, 83,61\% mahasiswa mengetahui bahaya rokok. Sikap mahasiswa di lingkungan Universitas Pakuan dalam mengkonsumsi rokok relatif sedang, yaitu sebanyak 55,83\% bukan perokok dan $44,17 \%$ responden adalah perokok. Dalam pertimbangan pemilihan rokok di kalangan mahasiswa, kecenderungannya adalah faktor rasa merupakan faktor yang lebih dominan setelah merk dan harga juga faktor media iklan yang dapat menarik perhatian. Kekurangan penelitian ini adalah Tidak melakukan wawancara yang mendalam sebagai data tambahan dalam pembahasan ${ }^{4}$.

b. Jurnal oleh Melisa Lenardi dengan judul penelitian "Label visual peringatan pada bungkus rokok: upaya mutakhir penekanan angka perokok di Indonesia" Universitas Indonesia Fakultas Ilmu Sosial dan Ilmu Politik pada tahun 2004, Metode penulisan yang digunakan adalah metode studi kepustakaan. Sumber- sumber kepustakaan yang dipergunakan adalah jurnal kedokteran, buku teks, dan informasidari internet. Metode pemilihan sumber menggunakan kaidah penulisan karya tulis ilmiah. Merokok dapat menyebabkan gangguan pada kesehatan dan kesejahteraan bangsakarena dapat menyebabkan berbagai penyakit serta menyebabkan kerugian secaramateri.

\footnotetext{
${ }^{4}$ Yudha Mulyana "Analisis perilaku konsumen rokok dikalangan mahasiswa Universitas Pakuan" Fakultas Ekonomi Universitas Pakuan, Bogor, Jawa Barat 2012
} 
Permasalahan saat ini adalah kebijakan mengenai rokok untuk memberikan edukasi yang efektif untuk meningkatkan kesadaran masyarakat masih kurang berhasil, kekurangn pada penelitian ini adalah sumber data yang diperoleh pada penelitian ini terlalu banyak melakukan observasi langsung, tanpa melibatkan sumber lain ${ }^{5}$.

c. Jurnal oleh Sri Widati dengan judul penelitian "Efektivitas pesan bahaya rokok pada bungkus rokok terhadap perilaku merokok masyarakat miskin” Jurnal Promkes, Vol. 1, No. 2 Desember 2013. Penelitian ini merupakan penelitian deskriptif dengan metode pengambilan data kuantitatif dan kualitatif dengan kuesioner dan wawancara mendalam. Hasil penelitian ini yaitu Pesan bahaya rokok di bungkus rokok belum bisa menaikkan pengetahuan informan mengenai substansi rokok, bahaya rokok bagi diri sendiri, bahaya rokok bagi orang lain ataupun mengenai cara merokok dan dampaknya bagi kesehatan. kekurangn pada penelitian ini adalah Terlalu fokus pada makna secara kuantitatif, dan tidak memperdalam makna kualitatif 6 .

\section{METODE PENELITIAN}

Penelitian ini mengunakan metode kualitatif dengan pendekatan studi kasus, dimana menurut Zikri Facrul studi kasus merupakan suatu penelitian yang dilakukan secara intensif, terinci, dan mendalam terhadap suatu organisasi, lembaga atau gejala tertentu ${ }^{7}$. Menurut Robert K. Yin Penelitian case study atau penelitian lapangan (field study) dimaksudkan untuk mempelajari secara intensif tentang latar belakang masalah keadaan dan posisi suatu peristiwa yang sedang berlangsung saat ini, serta interaksi lingkungan unit sosial tertentu yang bersifat apa adanya (given). Subjek penelitian dapat berupa individu, kelompok, institusi atau masyarakat. Selain juga bertujuan meningkatkan pengetahuan mengenai peristiwa-peristiwa komunikasi kontemporer yang nyata dalam konteksnya ${ }^{8}$.

\footnotetext{
${ }^{5}$ Melisa Lenardi“Label visual peringatan pada bungkus rokok: upaya mutakhir penekanan angka perokok di Indonesia" Jurnal ilmiah Universitas Indonesia Fakultas IImu Sosial dan IImu Politik 2004.

${ }^{6}$ Sri Widati "Efektivitas pesan bahaya rokok pada bungkus rokok terhadap perilaku merokok masyarakat miskin" Jurnal Promkes, Vol. 1, 2013.

${ }^{7}$ Zikri, Fachrul Nuradi. Teori-teori Komunikasi. (Bogor: Ghalia Indonesia, 2015) h.161.

${ }^{8}$ Yin, Robert K. Studi Kasus Desain \& Metode. Jakarta: PT Raja Grafindo Persada, 2002) h.1
} 
Pada penelitian ini studi kasus menelusuri beberapa keunikan menarik karena adanya relevansi terhadap masalah yang di angkat, di antaranya : Berdasarkan keunikan yang telah diuraikan diatas maka penelitian ini termasuk pada studi kasus instrumental tunggal (single instrumental case study) yaitu penelitian studi kasus yang dilakukan dengan menggunakan sebuah kasus untuk menggambarkan suatu isu atau perhatian. Pada penelitian ini, peneliti memperhatikan dan mengkaji suatu isu yang menarik perhatiannya, dan menggunakan sebuah kasus sebagai sarana untuk menggambarkannya secara terperinci.

Analisis dilakukan dengan cara mengumpulkan data yang berasal dari beberapa pihak dan ditinjau kembali pada anggota kelompok Arsenal Indonesian Supporter (AIS) regional Bandung yang perokok. Dengan begitu sisi keunikan dalam masalah ini akan terlihat untuk mengetahui persepsi anggota kelompok Arsenal Indonesian Supporter (AIS) regional Bandung terhadap komunikasi visual peringatan pada bungkus rokok "edisi paruparu rusak".

Peneliti menggunakan triangulasi sebagai teknik untuk mengecek keabsahan data. Dimana dalam pengertiannya triangulasi adalah teknik pemeriksaan keabsahan data yang memanfaatkan sesuatu yang lain dalam membandingkan hasil wawancara terhadap objek penelitian. Triangulasi dapat dilakukan dengan menggunakan teknik yang berbeda yaitu wawancara, observasi dan dokumen.

\section{HASIL DAN PEMBAHASAN}

Komunikasi menurut Bernard Barelson \& Garry A. Steiner adalah proses transmisi informasi, gagasan, emosi, keterampilan dan sebagainya dengan menggunakan simbolsimbol, kata-kata, gambar, grafis, angka, dan sebagainya ${ }^{9}$. Bentuk komunikasi penyampaian melalui media gambar adalah komunikasi visual. Komunikasi visual merupakan komunikasi melalui penglihatan, sebuah rangkaian proses penyampaian infromasi atau pesan kepada pihak lain dengan penggunaan media penggambaran yang hanya terbaca oleh indera penglihatan. Komunikasi visual mengkombinasikan seni,

\footnotetext{
${ }^{9}$ Mulyana Deddy. Ilmu Komunikasi Suatu Pengantar (Bandung: PT Remaja Rosdakarya, 2005)
} h.62. 
lambang, gambar, desain grafis, ilustrasi, tipografi, dan warna dalam penyampaiannya Menurut Michael kroeger dalam buku Sitepu ${ }^{10}$.

Komunikasi visual pada penelitian ini melibatkan gambar peringatan yang tertera pada semua bungkus rokok yang beredar di seluruh Indonesia oleh emerintah, dimana pemerintah itu sendiri memiliki tujuan yaitu menekan angka pengkonsumsi rokok yang semakin naik dari tahun ke tahun. dan ternyata pada kenyataan dilapangan berdasarkan hasil wawancara dan observasi secara langsung oleh peneliti, komunikasi visual pada bungkus rokok yang tertuju kepada masyarakat khususnya kepada anggota komunitas Arsenal Indonesian Supporter regional Bandung yang merokok mendapat respon yang cukup baik yang dapat dinilai dari persepsi anggota komunitas Arsenal Indonesian Supporter regional Bandung yang perokok aktif, maupun perokok pasif terhadap pesan peringatan pada bungkus rokok edisi paru-paru rusak.

\section{a. Persepsi Anggota AIS Bandung dalam menanggapi visual peringatan pada bungkus rokok}

Persepsi merupakan perlakuan yang melibatkan penafsiran melalui proses pemikiran tentang apa yang dilihat, dengar, alami atau dibaca, sehingga persepsi sering memengaruhi tingkah laku, percakapan serta perasaan seseorang. Dalam penelitian ini persepsi anggota Arsenal Indonesian Supporter regional Bandung terhadap pesan edisi "paru-paru rusak" pada bungkus rokok dan setelah melakukan observasi dan wawancara mendalam maka menurut salah satu informan yang ditemui oleh peneliti dan melakukan interview mendalam, maka didapat bahwa makna pesan pada bungkus rokok tersebut sangat tersampaikan kepada anggota komunitas khususnya para perokok.

Dari hasil penelitian yang dilakukan dilapangan, hal yang pertama peneliti melihat anggota komunitas Arsenal Indonesian Supporter (AIS) regional Bandung ini mulai terbentuk karena dilatar belakangi oleh beberapa individu yang memiliki kesamaan, sehingga menjadi satu kesatuan yang disebut kelompok atau komunitas, hal ini diutarakan oleh Key informan peneliti yaitu Rega sebagai ketua komunitas Arsenal Indonesian Supporter (AIS) regional Bandung:

"Awalnya itu menghilangnya tayangan liga utama Inggris pada musim sekitar 2007-2008 di salah satu stasiun televisi swasta, dan kita sebagai

${ }^{10}$ Sitepu Vinsensius. Panduan Mengenal Desain Grafis (Jakarta, 2004) h.11-12. 
pencinta EPL (English Premier League) waktu itu menjadikan hal ini awal momen baik, dimana kita menjadi sering untuk bersama-sama menonton tayangan EPL (English Premier League) di warung kopi yang menggunakan saluran tv satelit, dari sana kita akhirnya yang satu penggemar team Arsenal memiliki ide untuk membentuk suatu komunitas dimana menjadi wadah bagi fans Arsenal untuk nonton bareng, yang kemudian komunitas ini berkembang dengan berbagai macam kegiatannya" 11

Secara umum bahaya merokok bagi kesehatan itu sendiri sudah diketahui oleh komunitas Arsenal Indonesian Supporter regional Bandung, bahaya yang telahdiketahui anggota komunitas yang perokok tersebut adalah seperti yang sudah tercantum pada kemasan-kemasan rokok yang telah beredar, seperti penyakit kanker, serangan jantung, impotensi dan gangguan kehamilan janin. Anggota komunitas perokok tersebut juga sudah merasakan dampak negatif pada kesehatan mereka, akibat dari intensitas merokok yang bisa dikatakan sebagai perokok aktif, anggota komunitas perokok tersebut merasakan gangguan pada pernafasan mereka, dada yang sering kali terasa sesak dan sulit untuk bernafas, kebugaran fisik yang mulai menurun juga sangat dirasakan oleh sebagian anggota komunitas perokok tersebut saat mereka melakukan aktivitas yang cukup menguras tenaga, dan hal itu sangat berbeda ketika mereka belum mengenal ataupun belum mengkonsumsi rokok.

Gambar peringatan tersebut cukup beraneka ragam karena terdapat berbagai macam gambar yang menyeramkan dan menjijikkan. Gambar peringatan bahaya merokok yang telah dibuat oleh pemerintah tersebut meliputi gambar paru-paru rusak, kanker mulut, kanker tenggorokan, gambar seseorang menggendong bayi yang menandakan bahwa merokok berbahaya bagi anak serta gambar merokok membunuhmu yang terdapat gambar tengkorak. Anggota AIS menganggapi Peraturan Pemerintah mengenai gambar bahaya merokok pada kemasan rokok tersebut tergolong baik, namun menurut mereka hal tersebut masih belum maksimal keefektifannya. Hal ini dapat ditunjukkan bahwa Anggota AIS Bandung masih ada yang tetap merokok meskipun sudah berkurang intensitasnya, dan faktanya rokok masih sangat laku di

${ }^{11}$ Kutipan dari wawancara dengan ketua AIS regional Bandung 
kalangan masyarakat umum juga. Anggota AIS Bandung mengaku memiliki perasaan yang jijik dan takut saat melihat gambar bahaya merokok yang menyeramkan tersebut.

\section{b. Pemahaman Anggota AIS Bandung Mengenai Pesan yang Disampaikan pada Bungkus Rokok}

Pemahaman bukan sekedar mengetahui, yang bisanya hanya sebatas mengingat kembali pengalaman dan memproduksi apa yang pernah dipelajari. Pemahaman lebih dari sekedar mengetahui, karena pemahaman melibatkan proses mental yang dinamis. Pemahaman merupakan suatu proses bertahap yang mempunyai kemampuan tersendiri seperti menerjemahkan, menginterprestasi, eksplorasi, aplikasi, analisis, sintesis, dan evaluasi.

Persepsi mereka mengenai pesan pada bungkus rokok edisi paru-paru rusak cenderung sesuai dengan apa yang diharapkan, karena kebijakan-kebijakan pemerintah dalam menekan angka pengkonsumsi rokok mulai dari kebijakan tulisan peringatan yang bertuliskan larangan-larangan, hingga kebijakan saat ini tidak hanya dengan beberapa macam tulisan peringatan, namun juga dengan menggunakan gambar-gambar dengan beberapa tema yang berbeda pula. Dan anggota komunitas AIS Bandung ini memiliki pandangan yang positif dan mendukung usaha pemerintah mengenai pesan yang disampaikan melalui komunikasi visual pada bungkus rokok edisi paru-paru rusak dengan tujuan mengurangi perokok yang ada didalam komunitas AIS tersebut. Pemahaman mengenai gambar bahaya merokok pada kemasan rokok berbeda- beda.

Berdasarkan observasi dan interview pihak terkait, peneliti mengungkapan terdapat temuan-temuan dalam penelitian ini sebagai berikut:

1. Gambar peringatan bahaya merokok pada kemasan rokok dapat mengurangi intensitas perokok pada masyarakat umum atau dapat mencegah masyarakat umum yang belum merokok, termasuk mengurangi intensitas merokok bagi anggota komunitas AIS Bandung.

2. Gambar peringatan bahaya merokok pada kemasan rokok memberikan kesan menakutkan dan menjijikkan bagi perokok.

3. Terdapat persepsi anggota AIS Bandung yang mengungkapkan bahwa intensitas merokok akan dapat berkurang jika harga rokok dinaikkan. 


\section{c. Latar Belakang Budaya Anggota AIS Bandung Dalam Membentuk Persepsi Mengenai Bungkus Rokok}

Faktor-faktor internal bukan saja mempengaruhi atensi sebagai salah satu aspek persepsi, tetapi juga mempengaruhi persepsi kita secara keseluruhan, terutama penafsiran atas suatu rangsangan. Persepsi merupakan salah satu aspek psikologis yang penting bagi manusia dalam merespon kehadiran berbagai aspek dan gejala di sekitarnya. Persepsi mengandung pengertian yang sangat luas, menyangkut intern dan ekstern. Berbagai ahli telah memberikan definisi yang beragam tentang persepsi, walaupun pada prinsipnya mengandung makna yang sama. Menurut Kamus Besar Bahasa Indonesia, persepsi adalah tanggapan (penerimaan) langsung dari sesuatu. Proses seseorang mengetahui beberapa hal melalui panca inderanya ${ }^{12}$. Dengan demikian persepsi itu terkait oleh budaya kelompok - kelompok budaya boleh jadi berbeda dalam mempersepsikan sesuatu, banyak faktor dan juga banyak hal-hal yang menjadi pendukung terciptanya atau terbentuknya persepsi pada setiap orang, salah satunya adalah latar belakang budaya pada anggota AIS Bandung.

Kebiasaan yang terus menerus dilakukan dalam jangka waktu yang cukup lama menjadikan kebiasaan tersebut menjadi kebudayaan Seiring dengan perubahaan kebudayaan inilah menyadarkan dan membuat pandangan anggota AIS Bandung terhadap kegiatan merokok menjadi negatif, mereka memiliki persepsi yang pada dasarnya sama.

Manusia pada dasarnya saling membutuhkan satu sama lain dalam berbagai aspek kehidupan bermasyarakat. Dari hubungan tersebut tercipta suatu kehidupan sosial yang berperan didalamnya. Salah satu bentuk umum dalam proses sosial adalah interaksi yang terjadi setiap hari antar individu. Interaksi yang telah terbentuk akan menjadi suatu yang vital dan menjadi sebuah kebutuhan dalam masyarakat luas, selain itu kaitan interaksi ini dengan seorang individu adalah memberikan sebuah nilai pengalaman ataupun pesan hidup yang didapatkan dari komunikasi interaksi secara terus-menerus antar individu dalam satu komunitas. Kemudian akan terbentuklah sebuah persepsi mengenai pesan peringatan label visual pada bungkus

${ }^{12}$ Ali Nurdin dkk, Pengantar Ilmu Komunikasi, (Surabaya: IAIN Press, 2013), hlm. 159 
rokok edisi "paru-paru rusak" tersebut dalam komunitas AIS Bandung. ${ }^{13}$

\section{d. Komunitas AIS Bandung Sebagai Pembentuk Persepsi Anggotanya Terhadap Visual Bungkus Rokok}

Komunitas AIS Bandung terbentuk oleh berbagai tujuan, pandangan dan pemahaman tentang pengetahuan menciptakan proses. Berbagi pengalamaman menciptakan keyakinan mendalam dan aturan dasar tentang menjadi anggota komunitas AIS Bandung tersebut. Pemahaman pengetahuan menciptakan proses yang menjadikan sebuah anggotanya dapat melihat apakah kegiatan mereka berguna bagi lingkungan sekitarnya dan usaha yang terus-menerus untuk menciptakan hubungan antar anggota.

Dengan sudah dimulainya kegiatan-kegiatan komunitas AIS Bandung yang peduli akan kesehatan dan kegiatan positif lainnya, maka peneliti dapat mengambil kesimpulan bahwa komunitas AIS Bandung secara tidak langsung telah berperan dalam membentuk persepsi anggotanya terhadap menilai dan menanggapi pesan yang disampaikan oleh pemerintah dalam menekan angka konsumen perokok melalui visual peringatan pada bungkus rokok.

Komunitas Arsenal Indonesian Supporter Regional Bandung ini sudah berdiri sejak lama dengan banyak kegiatan, berawal dengan kegiatan nonton bareng pertandingan sepak bola, hingga saat ini komunitas ini memiliki kegiatan donor darah, futsal bareng, jambore nasional, sayembara ke London, dan sebagainya.

Dimana hampir seluruh kegiatan tersebut komunitas melarang anggota komunitasnya untuk merokok, hal tersebut secara tidak langsung memberikan informasi positif secara kognitif kepada anggota komunitas bahwa tidak merokok akan sangat baik bagi individu dan juga bagi komunitas tersebut yang tentunya membetuk persepsi mereka masing-masing dalam menanggapi gambar peringatan pada bungkus rokok edisi "paru-paru rusak".

${ }^{13}$ http://kompasiana.com 


\section{E. KESIMPULAN}

Berdasarkan hasil penelitian yang telah dilakukan maka dapat ditarik beberapa kesimpulan yang merangkum seluruhnya, diantaranya sebagai berikut :

a. Berdasarkan hasil penelitian yang telah dilakukan maka dapat ditarik beberapa kesimpulan yang merangkum seluruhnya, diantaranya sebagai berikut: Persepsi komunitas Arsenal Indonesian Supporter regional Bandung dalam menanggapi gambar bahaya merokok pada kemasan rokok merupakan hal baik yang dibuat oleh pemerintah, karena dapat menekan jumlah perokok di Indonesia dan dapat mencegah masyarakat umum termasuk anggota komunitas Arsenal Indonesian Supporter regional Bandung untuk tidak mencoba atau melanjutkan mengkonsumsi rokok. Anggota komunitas Arsenal Indonesian Supporter regional Bandung mengakui bahwa dengan adanya pencantuman gambar tersebut mereka juga merasa jijik dan takut dengan gambar tersebut.

b. Pemahaman anggota komunitas Arsenal Indonesian Supporter regional Bandung terhadap pesan yang disampaikan dalam gambar peringatan pada bungkus rokok tergolong cukup baik. mereka mengetahui bahaya yang ditimbulkan akibat merokok terutama terkait dengan kesehatan seperti kanker mulut, kanker tenggorokan, kanker paru-paru, gangguan jantung, dan sebagainya.

c. Latar belakang anggota komunitas Arsenal Indonesian Supporter regional Bandung dalam membentuk persepsi mengenai gambar peringatan pada bungkus rokok bermacam-macam antara lain faktor keluarga, penghasilan, lingkungan, pendidikan, dan kebudayaan, dalam penelitian ini faktor kebudayaanlah yang paling mempengaruhi hal tersebut, mengingat di negara kita kebiasaan merokok adalah suatu kebiasaan yang 
sudah sangat mengakar di berbagai golongan masyarakat yang turun temurun dan menjadikannya sebagai budaya.

d. Komunitas Arsenal Indonesian Supporter (AIS) regional Bandung adalah salah satu faktor penting yang menjadikan anggota komunitas membentuk persepsi terhadap komunikasi visual bungkus rokok di komunitasnya tersebut, salah satu alasannya adalah karena komunitas ini sangat ingin menjadikan seluruh kegiatannya sehat tanpa asap rokok. 


\section{DAFTAR PUSTAKA}

\section{BUKU:}

Ali Nurdin dkk, Pengantar Ilmu Komunikasi, 2013 Surabaya: IAIN Press

Mulyana Deddy. 2005. Ilmu Komunikasi Suatu Pengantar. Bandung: PT Remaja Rosdakarya

Moleong Lexy J. 2004. Metodologi Penelitian Kualitatif. Bandung: PT Remaja Rosdakarya

Sitepu Vinsensius 2004. Panduan Mengenal Desain Grafis: Jakarta

Yin, Robert K. 2002. Studi Kasus Desain \& Metode. Jakarta: PT Raja Grafindo Persada.

Zikri, Fachrul Nuradi. 2015. Teori-teori Komunikasi. Ghalia Indonesia: Bogor

\section{JURNAL:}

Yudha Mulyana "Analisis perilaku konsumen rokok dikalangan mahasiswa Universitas Pakuan" Fakultas Ekonomi Universitas Pakuan, Bogor, Jawa Barat 2012

Melisa Lenardi "Label visual peringatan pada bungkus rokok: upaya mutakhir penekanan angka perokok di Indonesia" Jurnal ilmiah Universitas Indonesia Fakultas Ilmu Sosial dan Ilmu Politik 2004.

Sri Widati "Efektivitas pesan bahaya rokok pada bungkus rokok terhadap perilaku merokok masyarakat miskin” Jurnal Promkes, Vol. 1, 2013.

\section{INTERNET:}

http://id.wikipedia.com

http://www.bisnis.com

http://www.kemenperin.go.id

http://kompasiana.com 